\title{
Multiprobiotic therapy from childhood prevents the development of nonalcoholic fatty liver disease in adult monosodium glutamate-induced obese rats
}

\author{
Maryana Kondro ${ }^{1}$, Nazarit Kobyliak ${ }^{2}$, Oleksandr Virchenko ${ }^{3}$, \\ Tetyana Falalyeyeva ${ }^{3 *}$, Tetyana Beregova ${ }^{3}$, Petro Bodnar ${ }^{2}$
}

\author{
${ }^{1}$ Danylo Halytsky Lviv National Medical University, Ukraine \\ ${ }^{2}$ Bogomolets National Medical University, Ukraine \\ ${ }^{3}$ Taras Shevchenko National University of Kyiv, Volodymyrska 64/13, Kyiv, 01601, Ukraine
}

\section{ARTICLE INFO \\ Received 07 November 2014 Accepted 12 December 2014}

\section{Keywords:}

monosodium glutamate, non-alcoholic fatty liver disease,

multiprobiotic.

\begin{abstract}
Considering the association between microflora and obesity, and the significantly higher prevalence of non-alcoholic fatty liver disease (NAFLD) in obese people, the aim of our study was to investigate the preventive effect of multiprobiotics on the monosodium glutamate (MSG) induced NAFLD model, in rats. The work was carried out on 60 rats placed into three groups: the Control group, the MSG-group and the MSG-probiotic group. The MSG-group and the MSG-probiotic group were injected with $4 \mathrm{mg} / \mathrm{g}$ of MSG subcutaneously neonatally on the $2^{\text {nd }}-10^{\text {th }}$ days of life. The MSG-probiotic rats were also treated with $140 \mathrm{mg} / \mathrm{kg}$ of multiprobiotic "Symbiter" from the $4^{\text {th }}$ week of life. In the 4-month-old rats, biochemical and morphological changes in liver were assessed, and steatosis was confirmed by the NAFLD activity score (NAS). Our results reveal that the multiprobiotic lowered total NAS, the degree of steatosis and the liver lobular inflammation caused by MSG. It also brought about decreased liver total lipids and triglycerids content, as well as decreased visceral adipose tissue mass. However, there was no difference in the liver serum biochemical indicators between all experimental groups. The obtained data does suggest the efficacy of probiotics in the prevention of NAFLD.
\end{abstract}

\section{INTRODUCTION}

Non-alcoholic fatty liver disease (NAFLD) ranges from simple steatosis, to non-alcoholic steatohepatitis (NASH), and can show different degrees of fibrosis and progress towards liver cirrhosis and end-stage liver disease. The prevalence of NAFLD in the general population reaches $15-20 \%$. This figure goes up to 76 to $90 \%$ within population that is considered to be obese [1].

The gut's microbiota has been recently proposed to be an environmental factor involved in the control of body weight and energy homeostasis [3,9]. This "exteriorised organ" contributes to our homeostasis via its multiple metabolic

\footnotetext{
Corresponding author

e-mail: tfalalyeyeva@mail.ru

tel. +380677939039
}

functions and diverse control mechanisms, all of which are involved in the extraction of calories from ingested dietary substances. Moreover, the gut's microflora helps to store these calories in the host adipose tissue for later use [2,10]. Probiotics have been suggested as a treatment for the prevention of chronic liver damage, because they prevent bacterial translocation and epithelial invasion, and also because they inhibit bacterial mucosal adherence, as well as the production of antimicrobial peptides, while decreasing inflammation and stimulating host immunity $[4,5,7]$. Considering the association between microflora and metabolism, and the significantly higher prevalence of NAFLD in people with impaired metabolism, we aimed to investigate the preventive effect of multiprobiotic on the monosodium glutamate (MSG) induced NAFLD model in rats. 


\section{MATERIAL AND METHODS}

Our study was performed on 60 newborn Wistar rats placed into 3 groups (see experiment design, Table 1). The degree of obesity was obtained by way of the Lee index, which was calculated as the cube root of body weight $(\mathrm{g}) /$ naso-anal length $(\mathrm{cm})$. A value of this index equal to or less than 0.300 was classified as normal. Rats presenting values higher than 0.300 were classified as obese [8]. Administration of multiprobiotic "Symbiter", containing a concentrated biomass of 14 probiotic bacteria of Bifidobacterium, Lactobacillus, Lactococcus, Propionibacterium genera, was started at the end of the $4^{\text {th }}$ week after birth, and continued intermittently as a two-week course, in 2 week intervals.

The animals were handled accordingly to ethical standards set out by the National Institute of Health Guidelines for the Care and Use of Laboratory Animals and the European Community Council Directive of 24 November 1986, for Care and Use of Laboratory Animals (86/609/ EEC), and approved by the local ethics committee.

After decapitation, blood and liver tissue samples $(5 \times 5 \mathrm{~mm})$ were taken for biochemical and morphological studies. To assess morphological changes in the liver, we used the NAS (NAFLD activity score). NAS scale total score $\leq 3$ eliminates NASH and confirmed simple steatosis. Lipid extraction from the liver samples was performed according to Folch et al. [6].

Table 1. Experiment design and experimental groups

\begin{tabular}{|c|c|c|}
\hline I & II & III \\
\hline $\begin{array}{l}\text { Control group } \\
(n=20)\end{array}$ & $\begin{array}{l}\text { Monosodium glutamate } \\
\text { (MSG)-obesity }(n=20)\end{array}$ & $\begin{array}{l}\text { MSG + probiotic } \\
\quad(n=20)\end{array}$ \\
\hline $\begin{array}{c}8 \mu \mathrm{l} / \mathrm{g} \text { of water at } \\
2,4,6,8,10 \text { days of life }\end{array}$ & $\begin{array}{l}8 \mu \mathrm{l} / \mathrm{g} \text { of MSG }(4 \mathrm{mg} / \mathrm{g}) \text { at } \\
2,4,6,8,10 \text { days of life }\end{array}$ & $\begin{array}{c}8 \mu \mathrm{l} / \mathrm{g} \text { of MSG }(4 \mathrm{mg} / \mathrm{g}) \text { at } \\
2,4,6,8,10 \text { days of life }\end{array}$ \\
\hline $\begin{array}{l}\text { Water in a volume } \\
\text { of } 0.25 \mathrm{ml} / 100 \mathrm{~g} \\
\text { (two-week courses } \\
\text { for } 3 \text { months) }\end{array}$ & $\begin{array}{l}\text { Water in a volume } \\
\text { of } 0.25 \mathrm{ml} / 100 \mathrm{~g} \\
\text { (two-week courses } \\
\text { for } 3 \text { months) }\end{array}$ & $\begin{array}{c}\text { Aqueous solution of } \\
\text { multiprobiotic Symbiter } \\
(140 \mathrm{mg} / \mathrm{kg} \text { ) in a volume } \\
\text { of } 0.25 \mathrm{ml} / 100 \mathrm{~g} \\
\text { (two-week courses } \\
\text { for } 3 \text { months) }\end{array}$ \\
\hline
\end{tabular}

Statistical analysis was performed by using SPSS-20 software. Continuous variables were analyzed using Analysis of Variance (ANOVA) or Kruskall-Wallis tests. For comparisons of categorical variables, we conducted the $\chi^{2}$ test. In all analyses, a $p$-value of $\leq 0.05$ was considered statistically significant.

\section{RESULTS}

We found a significantly lower total score $(0.95 \pm 0.15$ vs $3.3 \pm 0.28, p<0.001)$, degree of steatosis $(0.85 \pm 0.13$ vs $2.15 \pm 0.16, \mathrm{p}<0.001)$ and manifestation of lobular inflammation $(0.1 \pm 0.06$ vs $0.95 \pm 0.15, \mathrm{p}<0.001)$ due to NAFLD activity in the MSG-probiotic group, compared to the MSG-obesity group (Tab. 2). In the MSG-obesity group, moderate centrilobular microvesicular steatosis, and scattered infiltration of neutrophils and lymphocytes was observed, compared with mild steatosis without signs of lobular inflammation in the MSG-probiotic rats. NASH was confirmed only in $20 \%$ of the rats with MSG-obesity $(\mathrm{p}=0.035)$.
Table 2. Morphological changes in rats liver assessed by NAFLD activity score (NAS)

\begin{tabular}{|l|c|c|c|c|}
\hline & $\begin{array}{c}\text { Control group } \\
(n=20)\end{array}$ & $\begin{array}{c}\text { MSG-obesity } \\
(n=20)\end{array}$ & $\begin{array}{c}\text { MSG- } \\
\text { probiotic } \\
(n=20)\end{array}$ & $p$ \\
\hline Steatosis (0-3) & $0.10 \pm 0.1$ & $2.15 \pm 0.16$ & $0.85 \pm 0.13$ & $<0.001$ \\
\hline $\begin{array}{l}\text { Lobular } \\
\text { inflammation (0-2) }\end{array}$ & $0.0 \pm 0.0$ & $0.95 \pm 0.15$ & $0.1 \pm 0.06$ & $<0.001$ \\
\hline $\begin{array}{l}\text { Ballooning } \\
\text { degeneration (0-2) }\end{array}$ & $0.0 \pm 0.0$ & $0.15 \pm 0.08$ & $0.0 \pm 0.0$ & 0.094 \\
\hline Total NAS (0-8) & $0.10 \pm 0.1$ & $3.3 \pm 0.28$ & $0.95 \pm 0.15$ & $<0.001$ \\
\hline $\begin{array}{l}\text { Prevalence of } \\
\text { NASH, } \%\end{array}$ & - & 20 & - & 0.035 \\
\hline
\end{tabular}

Data presented as $\mathrm{M} \pm \mathrm{SEM}$

Our work shows that Probiotic administration reduced total hepatic lipids (by 20.9\%, p < 0.001) and triglycerides (by $25 \%, \mathrm{p}<0.001$ ) content, as well as total amount of visceral fat $(7.21 \pm 0.47$ vs $17.24 \pm 0.31 \mathrm{~g}, \mathrm{p}<0.001)$, when compared to the MSG-obesity group (Fig. 1).
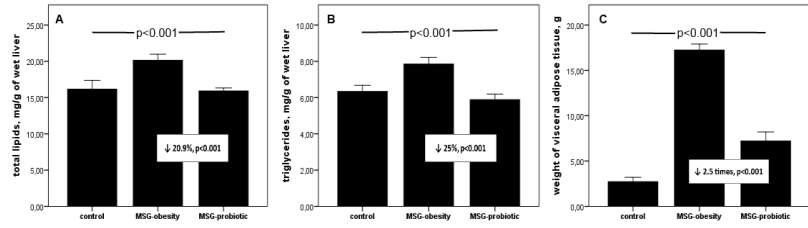

Figure 1. Liver total lipids (A), triglycerides (B) contents and visceral adipose tissue $(\mathrm{C})$ weight of rats under MSG-induced obesity and multiprobiotic correction $(\mathrm{M} \pm \mathrm{SEM})$

We did not find a significant difference in the biochemical indicators (alanine transaminase $(A L T)$, aspartate transaminase ( $A S T)$, albumin, bilirubin) of liver function, in the blood serum, between the MSG- and the MSG-probiotic groups (Table 3).

Table 3. Biochemical indicators of liver function in the blood serum of rats with glutamate-induced obesity, and that which was treated with probiotics

\begin{tabular}{|l|c|c|c|c|}
\hline & $\begin{array}{c}\text { Control } \\
(n=20)\end{array}$ & $\begin{array}{c}\text { MSG-induced } \\
\text { obesity } \\
(n=20)\end{array}$ & $\begin{array}{c}\text { MSG- } \\
\text { probiotic } \\
(n=20)\end{array}$ & $p$ \\
\hline ALT (mkkat/l) & $0,228 \pm 0,033$ & $0,211 \pm 0,031$ & $0,221 \pm 0,034$ & $>0,05$ \\
\hline AST (mkkat/l) & $0,389 \pm 0,034$ & $0,377 \pm 0,041$ & $0,392 \pm 0,044$ & $>0,05$ \\
\hline $\begin{array}{l}\text { Indirect albumin } \\
\text { (umol/l) }\end{array}$ & $7,9 \pm 1,7$ & $8,1 \pm 1,06$ & $7,7 \pm 1,4$ & $>0,05$ \\
\hline $\begin{array}{l}\text { Direct bilirubin } \\
\text { (mmol/l) }\end{array}$ & $4,4 \pm 0,91$ & $4,6 \pm 0,91$ & $4,6 \pm 0,97$ & $>0,05$ \\
\hline
\end{tabular}

Data represented as $\mathrm{M} \pm \mathrm{SEM}$

\section{CONCLUSIONS}

The administration of the multiprobiotic, "Symbiter", to neonatal MSG-treated rats in 2-week courses, led to a significant reduction of total body and visceral adipose tissue weight, as well as reduced total hepatic lipids and triglycerides levels. Furthermore, we observed the improvement of steatosis and lobular inflammation, as assessed by the NAS scale, in a group treated with this probiotic, compared to animals with MSG-obesity. Hence, short term periodic probiotic treatment from childhood has a preventive effect on NAFLD development. 


\section{REFERENCES}

1. Angulo P.: Medical progress: nonalcoholic fatty liver disease. The New England Journal of Medicine, 346, 16, 1221-1231, 2002.

2. Backhed F. et al.: The gut microbiota as an environmental factor that regulates fat storage. Proc. Natl Acad. Sci. USA, 101, 15718-15723, 2004.

3. Caricilli A.M., Saad M.J.: Gut microbiota composition and its effects on obesity and insulin resistance. CurrOpinClinNutrMetab Care, 17, 4, 312-318, 2014.

4. Cesaro C. et al.: Gut microbiota and probiotics in chronic liver diseases. Dig Liver Dis,43, 431-8, 2011.

5. Eslamparast T. et al.: Probiotics and Nonalcoholic Fatty liver Disease. Middle East J Dig Dis, 5, 3, 129-136, 2013.
6. Folch, J., Lees, M., Stanley, G.H.S: A simple method for the isolation and purification of total lipids from animal tissues. J. Biol. Biochem., 226, 497-509, 1957.

7. Frazier T.H., DiBaise J.K., McClain C.J.: Gut Microbiota, Intestinal Permeability, Obesity-Induced Inflammation, and Liver Injury. JPEN J Parenter Enteral Nutr,35, 14S-20S, 2011

8. Kondro M. et al.: Metabolic profile and morpho-functional state of the liver in rats with glutamate-induced obesity. Curr. IssuesPharm. Med. Sci.,26, 4, 379-381, 2013.

9. Raoult D, Henrissat B.: Are stool samples suitable for studying the link between gut microbiota and obesity? Eur J Epidemiol., 29, 5, 307-309, 2014.

10. Turnbaugh P.J. et al.: Diet-induced obesity is linked to marked but reversible alterations in the mouse distal gut microbiome. Cell Host Microbe, 3, 213-223, 2008 